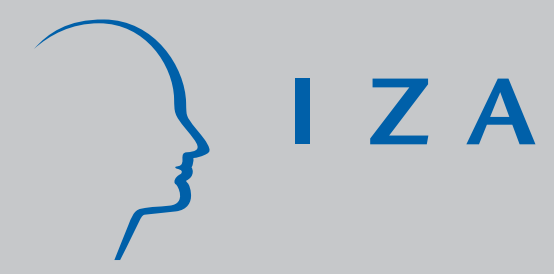

IZA DP No. 3459

Growing out of Poverty: Trends and Patterns of Urban Poverty in China 1988-2002

Simon Appleton

Lina Song

Qingjie Xia

April 2008 


\title{
Growing out of Poverty: Trends and Patterns of Urban Poverty in China 1988-2002
}

\author{
Simon Appleton \\ Nottingham University \\ Lina Song \\ Nottingham University \\ and IZA \\ Qingjie Xia \\ University of Peking
}

\section{Discussion Paper No. 3459 \\ April 2008}

IZA

P.O. Box 7240

53072 Bonn

Germany

\author{
Phone: +49-228-3894-0 \\ Fax: +49-228-3894-180 \\ E-mail: iza@iza.org
}

\begin{abstract}
Any opinions expressed here are those of the author(s) and not those of IZA. Research published in this series may include views on policy, but the institute itself takes no institutional policy positions.

The Institute for the Study of Labor (IZA) in Bonn is a local and virtual international research center and a place of communication between science, politics and business. IZA is an independent nonprofit organization supported by Deutsche Post World Net. The center is associated with the University of Bonn and offers a stimulating research environment through its international network, workshops and conferences, data service, project support, research visits and doctoral program. IZA engages in (i) original and internationally competitive research in all fields of labor economics, (ii) development of policy concepts, and (iii) dissemination of research results and concepts to the interested public.
\end{abstract}

IZA Discussion Papers often represent preliminary work and are circulated to encourage discussion. Citation of such a paper should account for its provisional character. A revised version may be available directly from the author. 
IZA Discussion Paper No. 3459

April 2008

\section{ABSTRACT \\ Growing out of Poverty: \\ Trends and Patterns of Urban Poverty in China 1988-2002}

This paper estimates trends in absolute poverty in urban China from 1988 to 2002 using the Chinese Household Income Project (CHIP) surveys. Poverty incidence curves are plotted, showing that poverty has fallen markedly during the period regardless of the exact location of the poverty line. Income inequality rose from 1988 to 1995 but has been fairly constant thereafter. Models of the determination of income and poverty reveal widening differentials by education, sex and party membership. Income from government anti-poverty programs has little impact on poverty, which has fallen almost entirely due to overall economic growth rather than redistribution.

JEL Classification: $\quad 015, \mathrm{J38}, \mathrm{O} 38$

Keywords: $\quad$ poverty, inequality, economic growth, welfare, public policy, China

Corresponding author:

Lina Song

School of Sociology and Social Policy

University of Nottingham

Nottingham, NG7 2RD

United Kingdom

E-mail: lina.song@nottingham.ac.uk 
Non-technical summary (500 words): There has long been controversy over the extent to which economic growth will reduce poverty. Some argue for "redistribution with growth" while others claim growth will "trickle down". In postreform China, governments have tended to emphasise the primacy of growth, as expressed in Deng Xiao-Ping's maxim "Let some get rich first". However, whilst rapid growth has been achieved, it is often claimed that this has been coupled with the creation of a "new urban poverty". A key concern has been with the distributional consequences of retrenchment within State Owned Enterprises and the resulting emergence of mass unemployment. The current Chinese government appears to have responded to these concerns by stressing the importance of a "harmonious society" rather than simply maximising economic growth.

This paper examines recent trends using the 1988 to 2002 Chinese Household Income Project (CHIP) surveys. These surveys are representative of all urban residents in China and provide the most detailed accounting of income available. A limitation of the data is the omission of most rural-urban migrants from the surveys.

Regardless of where the poverty line is set, it is clear that absolute poverty did fall over this period. The lower end of the income distribution has enjoyed rising real incomes. This is something of a paradox, given the emergence of large-scale unemployment in urban China after 1995. The explanation of this paradox is that the adverse effects of unemployment have been outweighed by strong rises in urban wages.

It is true that the incomes of the poor have risen less than those of others. But this much remarked upon rise in inequality occurred mainly in the period 1988-1995 as a result of the withdrawal of various subsidies and transfers. Since that time, inequality is shown has been relatively constant.

Income sources are decomposed to isolate the contribution of various anti-poverty programs - redundancy benefits, unemployment insurance and Minimum Living Standard. These programs are show to have little impact on poverty, which has fallen almost entirely due to overall economic growth rather than such redistributive measures.

Many income differentials have widened from 1988 to 2000. Differentials by education have grown, although are still fairly modest by international standards. The gender gap has widened. Communist Party members have also enjoyed an increased premium, although this trend appears to have gone into reverse since 1999.

From our analysis, urban China is growing out of poverty, at least when defined in absolute terms. However, there are several important caveats to this conclusion. First, our results apply only to registered urban residents, since most migrants are excluded from official surveys. Second, we do find that some inequalities have widened and that relative poverty has increased. Finally, we refer back to our findings on the ineffectiveness of government anti-poverty programs in reducing urban poverty. The government in China might be said to have gambled by heavily relying on economic growth to resolve many social problems including poverty reduction. One wonders what will happen if growth stops? 


\section{Introduction}

There is widespread debate over the relative role of economic growth and public redistribution in poverty reduction. After experiences such as the very inegalitarian growth of Brazil observed by Fishlow (1972), an international consensus evolved in the 1970s for "redistribution with growth". However, the 1980s saw the pendulum swing the other way, with a renewed emphasis being put on economic growth as central to poverty reduction. This stance was partly due to a belated recognition of the pro-poor growth of high performing East Asian economies (HPAEs) and the contrast with the crises in economically stagnant Latin America and Africa. Although the debate on redistribution and growth hinges partly on value judgements (for example, one's degree of inequality aversion), it is clear that country experiences of how economic growth is actually distributed have been very influential in shaping opinion. Cross-country experiences after 1960 imply that, on average, economic development does not have a systematic effect on inequality (Fields, 1991). Since there is no systematic tendency for inequality to change during growth, it follows that, on average, one should expect growth to tend to raise the incomes of the poor on a onefor-one basis. Again, cross-country evidence since 1960 supports this implication (Dollar and Kraay, 2000). However, these summary conclusions relate only to crosscountry averages and do not constitute an "iron law". In practice, as the contrasting experiences of Brazil and the East Asian HPAEs show, country experiences may deviate substantially from the norm.

The case of China is a particularly interesting one, not only because it is home to so many of the world's poor. Since the start of economic reforms 1978, it has enjoyed exceptionally rapid economic growth and the emphasis on government redistribution has been greatly reduced. The official stance is close to the "trickle down" theories emphasised in the 1980s: in the words of Deng Xiao-Ping, "let some get rich first". In the interests of promoting economic efficiency and hence growth, enterprises have been given more freedom in letting worker remuneration reflect productivity, excess workers in stated owned enterprises have been made unemployed and many state transfers have been removed. As Khan (1998) argues, post-reform, the Chinese government has tended to reject a "relief approach" to poverty reduction in favour of efforts to increase income generation. Indeed, Khan suggests that the reluctance of the 
Chinese government to adopt a redistributive approach to poverty reduction may partly be a backlash against the extreme egalitarianism of the planning period. Clearly, the efficacy of China's current strategy of emphasising economic growth over redistribution depends partly on the extent to which growth has actually reduced poverty.

We focus on poverty in urban China. For a long time, this topic was neglected by policy-makers and researchers. Government anti-poverty programs focussed on rural areas and, in particular, on selected poor counties. As Khan (1998, p42) commented "China's official poverty reduction strategy is based on the assumption that poverty is a rural problem." Within academia, few studies focussed on urban poverty, in contrast to the large literature on income distribution and inequality more generally. This neglect of urban poverty arose partly from using low poverty lines - such as a "dollar a day". Reflecting the great urban-rural divide in China (Knight and Song, 1999), a significant proportion of the rural population fell below these poverty lines but only $1 \%$ of the urban population were classified poor. With urban poverty in China being defined so as to concern only a very small minority, it is scarcely surprising that the issue was marginalised by government and scholars alike.

Things began to change in the second half of the 1990s with concern over what was seen as a "new urban poverty" caused partly by a wave of rural-urban migration and partly by mass unemployment following a program of retrenchment in state owned enterprises. These new forms of urban poverty differed from the old urban poverty which was often characterised as the "three withouts" - roughly corresponding to the disabled, the sick and the orphaned (Wong, 1998). By the turn of the century, opinion makers began to assert that urban poverty had risen during the 1990s, taking some of the shine off China's exceptionally high rates of economic growth. For example, The Economist (2001, page 39) declared "And in the cities, absolute poverty is increasing..." while the Chinese government magazine Liaowang (27 June 2002) also argued that urban poverty had increased. Underpinning such commentary was a concern that rising urban poverty would lead to political unrest, jeopardising the reforms that had enabled China's rapid economic growth (see Wu, 2004). However, urban poverty in China continued to be measured using low poverty lines such as "a 
dollar a day" that, despite perceived adverse developments, still only categorised around $1 \%$ of the urban population as poor.

In this paper, we use a range of higher poverty lines in order to consider more broadly how lower income urban households fared in the 1990s. We present new evidence based on the best available data-set on income distribution in China spanning the period from 1988 to 2002 . We find that concern over adverse poverty trends in the 1990s appear misplaced. There has perhaps been an over-reaction to the previous neglect of urban poverty in China, with unwarranted pessimism about the living standards of poorer households. In particular, we challenge the assertion that urban poverty rose in absolute terms. While this claim makes dramatic headlines, it is does not appear to be supported by the evidence.

The structure of the paper is as follows. Section 2 reviews the small existing literature on trends in urban poverty in China. Our own findings on trends in growth, inequality and poverty are documented in Section 3. Section 4 shows the results of decomposing changes in absolute poverty, focussing on the roles of economic growth, unemployment and government anti-poverty measures. Section 5 uses multivariate analysis to explore the patterns of poverty in the four different surveys we analyse. Section 6 summarises and concludes.

\section{Existing estimates of trends in urban poverty}

There are relatively few studies of urban poverty in China and these present seemingly contradictory conclusions on trends from 1988 to 2002. We confine ourselves to monetary measures of poverty, based on the use of household income or consumption as welfare measures, although we do not dispute that poverty can be viewed more broadly as having many dimensions (World Bank, 2001). Table 1 compiles estimates of the headcount of the urban poor made by these studies of monetary poverty. Some studies report that poverty has increased in the 1990s, others that it has shown no trend and yet more that that it has fallen. In this section, we review these studies and attempt to adjudicate between them. The task of adjudication is made somewhat easier by the fact that all rely on one of two main sources of data either the official NBS household survey results or the CHIP surveys used in this 
paper. We argue that the CHIP data is preferable due to its fuller accounting of income but it is not clear that a difference in data accounts for the conflicting results on poverty trends. As previously discussed, both data sources cover only residents with urban registration hukou and so exclude most rural-urban migrants.

Poverty analysis using the CHIP surveys has been restricted to a comparison of their results for 1988 and 1995 (Khan, 1998; Khan and Riskin, 2001). Anchoring the poverty line on the cost of obtaining 2150 calories per day, $8 \%$ of urban residents were estimated to be poor in 1988, rising to $8.8 \%$ in 1995 . Taking a lower poverty line, anchored on 2100 calories per day, the rise was sharper - going from $2.7 \%$ to 4.0\%. These results are the most comparable to those we present later in this paper, as we take the same CHIP data, but add in surveys for 1999 and 2002. We do not dispute Khan's analysis of the 1988 and 1995 survey, but show that the rise in poverty in that period was not sustained and indeed was clearly outweighed by the fall in poverty from 1995 to 2002 . It seems likely that the CHIP surveys imply less favourable estimates of poverty trends that the NSB figures. For example, Khan (1996) used tabulated NBS data to estimate that poverty fell from $7.42 \%$ in 1989 to $5.9 \%$ in 1994 . The discrepancy probably arises from the fact that only the CHIP surveys include in their income measure the various food and other subsidies to households that were gradually withdrawn between 1988 and 1995.

However, the picture of rising urban poverty given by Khan's comparison of 1988 and 1995 finds some support by the recent study by Meng, Gregory and Wang (2005) using NBS data. A key feature of this study is that it estimates a different poverty line for each year (and indeed each region). Meng et al. report a rise in urban poverty from 1988 to 1995 using either upper or lower bound estimates of the poverty line. Thereafter, poverty trends down but sufficiently slowly that even by 2000 the headcount remains higher than in 1988. Meng et al. argue that re-estimating the poverty line for each year is appropriate because it makes better allowance of the changing availability and price of foods, and for increased non-food requirements due to the withdrawal of various subsidies. These arguments have some merit, but the solution arguably causes greater biases than it corrects. In a period of economic growth such as urban China has enjoyed, people are likely to consume more expensive food, raising the cost of calories. As a result, the food component of the 
poverty lines used by Meng et al. will be rising over time. Moreover, non-food requirements are estimated as a mark-up based on the non-food share of the poor. By Engels' law, rising income leads to a rising non-food share and thus increases in estimated non-food requirements. Hence the non-food component of the poverty lines used by Meng et al. is also likely to be rising over time. Allowing poverty lines to rise in this way can lead to poverty appearing to rise despite increases in the real incomes of poorer urban residents.

The other studies using NBS data adopt poverty lines that are fixed in real terms but produce no consensus on poverty trends when using poverty lines are set to be very low. Two studies find no strong trend. Fang et al. (2002) used a subset of the NBS data - one representative city from each province. Chen and Wang (2002) used the full NBS data-set but like most other studies were dependent on official tabulations (grouped data). When using low poverty lines such as a "dollar a day", both studies find urban poverty fluctuate in the 1990s with no clear trends. Nonetheless both studies show marked falls in urban poverty in the 1990s when it is more broadly defined. More positive conclusions are made in two other studies of NBS income data. Wang, Shi and Zheng (2001) use interpolations from the officially tabulated grouped income and look for generalised Lorenz dominance from 1981 to 1999. They find that each year, with the exception of 1988, the generalised Lorenz curve of real income per capita dominates that for the previous year. This implies that social welfare rose year on year and hence poverty fell, regardless of what level the poverty line was set - so long as the line was constant in real terms over time. In perhaps the most authoritative study of NBS data, Ravallion and Chen (2004) devised a poverty line for urban China based on the cost of basic needs in collaboration with government statisticians that is likely to be adopted as China's official poverty line. Comparing household real incomes with the line they derive, they estimate urban poverty rates to have been $2.07 \%$ in 1988 , falling to $0.85 \%$ in $1995,0.57 \%$ in 1999 and $0.54 \%$ in 2002 .

How can we adjudicate between these seemingly conflicting results? Analysis of NBS data has reached mixed results when using low poverty lines - a dollar a day or thereabouts. The conflicting results of these studies using NBS data may be partly the outcome of using low poverty lines that define only a very small proportion of the 
urban population to be poor. Surveys may be less reliable in obtaining estimates for the very poorest - there are particular problems in sampling them and results may be very influenced by low outliers. These difficulties are likely to be particularly acute given that nearly all the studies use only official tabulated data with rather crude groupings. This requires interpolation that may be particularly difficult when dealing with only the extreme low end of the distribution. Somewhat higher poverty lines that are fixed over time reveal an improvement in the living standards of low income urban households during the 1990s. Arguably, the work on the CHIP data is the most authoritative since these surveys provided the most comprehensive measurement of income. To the extent that the period 1988 to 1995 saw a large reduction in government transfers, not adjusting for this is likely to lead to too optimistic an assessment of poverty trends. However, until this paper, analysis of poverty trends using the CHIP data has been limited to a comparison of 1988 and 1995. This limitation is particularly important because concerns about a possible rise in urban poverty arose mainly after the onset of radical state-owned enterprise reform in 1995.

\section{New evidence on trends in poverty, inequality and growth}

\subsection{Data and measurement}

This paper uses the Chinese Household Income Project surveys conducted by the Economics Institute, CASS, in 1988, 1995, 1999 and 2002 (Riskin, Zhao and Li, 2001). The surveys use sub-samples from the main nationally representative household survey programme conducted by the government National Bureau of Statistics. As a result, the surveys are reasonably large and designed to be representative of urban $\mathrm{China}^{1}$. However, in practice, Chinese urban surveys cover only residents with urban registration (hukou), and so exclude rural-urban migrants ${ }^{2}$.

A key strength of the CHIP surveys is that they provide a more comprehensive and accurate assessment of household income than official NBS data (see Khan et al, 1993). Our measure of income follows the conventions proposed by Khan (1993) and as such has two differences from those used by the NBS and some other studies ${ }^{3}$. First, it includes the value of various state transfers and subsidies that were particularly important in 1988. Since these transfers have been eroded, excluding 
them and focussing on private earnings would risk overestimating income growth and poverty reduction. The most important elements of these transfers in 1988 were food subsidies through the coupon system and housing subsidies. Second, it includes an estimate of imputed income from the rent of owner occupied housing. Rents rose during the 1990s, implying that a bias from their omission in the NBS estimates that is in the opposite direction to that from omitting subsidies. To adjust for changes in prices, we use the official province specific urban CPI figures. These allow for regional variations in prices.

There is no official urban poverty line in China as yet, although separate poverty lines have been set for various cities in order to determine eligibility for benefits (Minimum Living Support). As discussed in the previous section, studies of urban poverty have tended to use poverty lines based around calorific requirements and tend to find only a very small proportion of the population to be poor. For example, Ravallion and Chen (2004) estimate that less than $0.5 \%$ of the urban population fell under their poverty line in 2001. Khan $(1998$, p8) criticises the "dismally low poverty threshold" commonly used, saying "To use such a poverty threshold is to start with the presumption that there is no urban poverty.” We have sympathy with Khan's criticism of the very narrow definitions of poverty conventionally applied to urban China. It may still be useful for international comparisons or when applied to rural areas. However, restricting oneself to such a narrow definition of poverty means that what one concludes about the impact of growth or policy reform on urban poverty is of limited interest - pertaining as it would, in 2001, to less than $1 \%$ of the urban population. For example, in our CHIP survey data for 2002, it would lead to no households surveyed in Beijing being classified as poor. Arguably, rising living standards in urban China have made the use of a calorific anchor inappropriate when setting the poverty line, much as it is inapplicable to OECD countries. Researchers studying poverty in industrialised countries would not dismiss the topic merely because everyone in such countries could afford to buy sufficient calories. Arguably, as China prospers and industrialises, a narrow calorie-based poverty line becomes inappropriate. In this paper, we provide some estimates of poverty based on $\$ 2$ and $\$ 3$ a day poverty lines (using 1985 PPP dollars). These lines are ultimately arbitrary but arguably more informative than lines which pertain to less than $1 \%$ of the urban population. 
Some heat can be taken out of the debate over where to set the poverty line by "dominance analysis" - that is to say plotting poverty incidence curves against multiples of the poverty line to see if poverty comparisons are robust to the location of the poverty line (see Ravallion, 1992, for a discussion; Figure 2 and the surrounding discussion late in this paper provide an application here). As conventionally performed, dominance analysis requires that the poverty line is fixed in real terms that is to say, the poverty line is an absolute one, rather than being a relative line that moves with average living standards. We adopt such an absolute concept of poverty in this paper and indeed this is central to our subsequent findings. We do not deny that poverty has an irredeemably relative aspect - indeed this is implicit in our preference for a $\$ 2$ or $\$ 3$ poverty line for urban China over a $\$ 1$ or calorific line. Consequently, we also estimate the extent of poverty using a relative poverty line - specifically, half of median income in the year of the survey. Nonetheless, our central interest is in whether the urban poor have benefited materially from China's economic growth and an absolute concept of poverty is required to answer this question.

An important caveat to our argument is that the CHIP surveys on which we base our estimates of urban poverty are based on the government's official sampling frame. This has the advantage of making our samples representative of all Chinese with urban registration (hukou). However, it excludes the "floating population" of ruralurban migrants who lack urban hukous. This omission is regrettable since rural-urban migration increased dramatically in the period and rural-urban migrants were no doubt poorer as a group than residents with urban hukou. Nonetheless, all large-scale statistical studies of urban poverty in China in the period are subject to the same limitation as a result of the government's failure to properly cover rural-urban migrants in its official statistics. The planned next round of the CHIP surveys will explicitly include migrants, but for now researchers are limited by the data available. For brevity, we will not continuously repeat this caveat and use the term "urban poverty" in this paper to refer to poverty rates among those with urban hukou. While important equity issues arise when considering rural-urban migrants - notably in their lack of access to government services compared to urban residents - there is no real suggestion that migrants as a group have impoverished themselves by moving to the cities. If any thing, the presumption is that migration has provided a means by which 
they can escape poverty (Park, Du and Wang, 2004). What data we have on ruralurban migrants in 1999 shows that unemployment rates among them are negligible (Appleton et al. 2002). By contrast, the second half of the 1990s saw the emergence of mass unemployment among residents with urban hukous. Employees in loss-making State Owned Enterprises found themselves laid-off and enduring long spells of unemployment (Knight and Song, 2005). If one is to look for potential losers from China's reform process, our focus on the urban residents rather than the migrants seems appropriate.

\subsection{Trends in growth and inequality}

China's real GDP per capita (nationally, not urban-only) is estimated to have grown by $7.4 \%$ per annum between 1988 and 2002. The CHIP data thus imply substantially slower growth - 5\% per annum - in household real incomes per capita (Table 2 refers). However, this still implies a dramatic improvement in economic welfare. On average, urban Chinese households have around twice as much income per capita in 2002 as they did in 1988. There is also a marked change in the structure of income between 1988 and subsequent years. Subsidies and income in kind constitute a much smaller part of total household income after 1988. Ration coupons were abolished and housing subsidies shrank from 18\% of total income in 1988 to a mere $2.8 \%$ in 2002. This is important, as some studies of income inequality in China focus more narrowly on cash wage earnings. Neglecting to account for subsidies and in-kind, which have been largely withdrawn after 1988, will tend to overstate the rise in income during the period. In our data, the share of cash earnings by working household members has rose from $43 \%$ of all household income in 1988 to $60 \%$ in 2002.

The more inclusive measure of income in the CHIP surveys probably explains the discrepancy between the growth estimates from that data compared to those from the larger household surveys conducted by the NBS. NBS data imply higher growth during the period $-6.8 \%$ per annum compared to $5.1 \%$ (Table 3 refers). CHIP data record slower growth in the period 1988 to 1995, as subsidies were withdrawn, and also 1999 to 2002, as housing items contributed a smaller share to total income. By contrast, CHIP data imply higher growth between 1995 and 2002 as housing rental values rose rapidly. 
The focus of this paper is not on the average level of growth, but how growth has varied across the distribution of income and hence the impact on poverty and inequality. Table 4 reports income per capita at each decile; Figure 1 plots the implied annualised growth rates. The CHIP data show that income growth between 1988 and 2002 is greater, the higher up the income distribution one goes. We have already noted that average incomes virtually doubled in the period. However, for the lowest decile, the $10^{\text {th }}$ percentile, real income per capita only increased by a half ( $49 \%$ higher). For the highest decile, the 90 th percentile, incomes increased by $130 \%$. As a consequence, growth rates for the highest decile averaged $6.0 \%$ per annum, more than twice the $2.8 \%$ growth experienced by the poorest decile.

The interval between the first survey in 1988 and the second in 1995 is largely what accounts for the unequal pattern of growth over the full period. Between 1988 and 1995, incomes of the poor grew slowly: the poorest decile saw only slow growth in income in this early period $(0.8 \%$ per annum). By contrast, the top decile enjoyed very fast growth of $6.1 \%$ per annum. In the subsequent intervals between surveys, the pattern of growth across the deciles is much flatter and less marked. It is true that the growth is slower at the poorest three deciles than at the median - but the differences are more muted - particularly in the latest episode, 1999 to 2002. Income growth for the most affluent decile is also below the median in these intervals.

The fact that income grew less for poorer deciles than for more affluent ones implies an increase in inequality. This is demonstrated in Table 5 that presents a variety of different inequality indices. By any of the conventional indices, inequality rises substantially from 1988 to 2002 . For example, the Gini coefficient rises from 0.24 to 0.33. However, it is noticeable that most of the rise occurs between 1988 and $1995-$ for example, the Gini coefficient actually falls slightly between 1995 and 2002. Looking at the numbers in more detail, there is a modest rise in inequality between 1995 and 1999. There is outweighed by a fall in inequality between 1999 and 2002. The fall in inequality between the last two surveys is perhaps surprising given the evidence in Figure 1 that the poorer deciles experienced growth below the median. However this is outweighed by the fact that the most affluent also enjoyed below average growth. 


\subsection{Poverty trends}

The fact that incomes grew across the deciles implies that absolute poverty fell, so long as a reasonably broad poverty line is used. Figure 2 provides figures for the percentage of urban residents who are poor for a continuum of poverty lines. The poverty incidence curve for 2002 is below those for earlier years. This implies that the conclusion that absolute poverty has fallen is robust to the choice of poverty line. Measuring poverty simply in terms of the headcount of the poor is inadequate - we might refer to a wider class of poverty indicators, the P-alpha measures proposed by Foster, Greer and Thorbecke (1984), of which the headcount is merely one (that when alpha equals zero). However, one corollary of the "first order" dominance revealed in Figure 2 is that poverty must also be lower in 2002 than in earlier years on any Palpha poverty index, regardless of what value of alpha we choose. Thus we can say that the poverty gap (P1) and the squared poverty gap (P2) are lower in 2002 than 1988, irrespective of the poverty line chosen.

Figure 2 is not informative for very low poverty lines, like a "dollar a day" poverty line - this corresponds to a value of 1212 yuan per year in 2002 prices, or the point "12" on the graph. Less than $1 \%$ of the samples in each survey fall below such a line. Instead, we focus on two rather arbitrary poverty lines - a broad poverty line of $\$ 3$ per day and a narrower one of $\$ 2$. With the $\$ 3$ poverty line, the proportion of urban people who are poor falls from $36.4 \%$ in 1988 to $8.5 \%$ in 2002 (Table 6 refers). With the $\$ 2$ poverty line, the prevalence of poverty falls from $7.3 \%$ to $2.1 \%$.

Poverty also falls between each of the surveys for most poverty lines. The most noticeable case where the poverty incidence curves in Figure 2 cross is when comparing poverty in 1988 and 1995 . Here, for low poverty lines that identify less than $6 \%$ of people as poor in 1988, we can see that poverty is higher in 1995 than in 1988. This implies that living standards worsened for the poorest $5 \%$ of the population between 1988 and 1995. This helps to understand the finding in Table 6 that, using the $\$ 2$ a day poverty line, the poverty gap, P1, and the squared poverty gap, P2, are estimated to rise between 1988 and 1995. 
Table 6 also reports poverty indices adopting a relative approach to poverty. Specifically it presents poverty indicators for when the poverty line is defined to be one half of median income per capita in the survey of that year (i.e. allowing the poverty line to rise with growth). Since the incomes of poorer urban residents have tended to grow less than average incomes, relative poverty has risen. Under this approach, relative poverty rises from $3.8 \%$ in 1988 to $12.8 \%$ in 2002. Relative poverty rises in all years although the increase is more pronounced between 1988 and 1995 (when relative poverty reaches 9.3\%) and more modest between 1999 and 2002 (going from $11.8 \%$ to $12.8 \%$ ).

\section{Decomposing changes in absolute poverty}

Further insight into trends in recent poverty trends can be given by various decompositions. In this section, we use various decompositions to quantify the role of growth in poverty reduction; to explain the paradox of poverty reduction during the emergence of mass unemployment; and to gauge the effectiveness of China's social security system.

\subsection{Decomposition of poverty changes into growth and distribution components}

The problem with focussing on relative poverty is that by construction it does not allow changes in average income to impact on poverty - relative poverty can only change if the distribution of incomes changes. However, it is growth alone rather than redistribution that has raised the living standards of the poor in this period. Since inequality has risen, the distributional changes have been unfavourable to the poor. Table 7 decomposes the change in poverty into growth and redistribution components following Datt and Ravallion (1992). Under this decomposition, we start by describing a poverty measure $P_{t}$ in terms of the poverty line, $z$, its mean income, $\mu_{t}$, and $L_{t}$, a vector of parameters fully representing the income distribution curve. A change in poverty over dates $t$ and $t+n$ is then decomposed as follows:

$$
P_{t+n}-P_{t}=G+D+R
$$


Where the growth, $\mathrm{G}$, and the redistribution, $\mathrm{D}$, components are calculated as:

$$
\begin{aligned}
G & \equiv P\left(\frac{z}{\mu_{t+n}} ; L_{r}\right)-P\left(\frac{z}{\mu_{t}} ; L_{r}\right) \\
D & \equiv P\left(\frac{z}{\mu_{r}} ; L_{t+n}\right)-P\left(\frac{z}{\mu_{r}} ; L_{t}\right)
\end{aligned}
$$

with a residual, $\mathrm{R}$, remaining.

For brevity, we decompose the headcount (P0) index only - decompositions for the $\mathrm{P} 1$ and $\mathrm{P} 2$ are not reported in the tables but give qualitatively similar results. The strong impact of growth in reducing poverty is evident from the results. For example, using the three dollar a day poverty line, we find that if the poor had enjoyed the same rate of income growth between 1988 and 2002 as the means of our samples, then the percentage of urban Chinese who are poor would have fallen by 34.9 percentage points. Since only $36.4 \%$ lived under $\$ 3$ a day in 1988, such growth would have implied the virtual elimination of poverty as so defined. In reality, poverty fell by 27.8 percentage points - still very impressive, but short of what would have happened had there been no change in the distribution of income.

Table 7 shows that the distributional changes in income in the period have generally been unfavourable - as should be expected from the rise in inequality noted in Table 5. More revealingly, the impact on poverty of adverse distributional changes is estimated to have been substantial. For example, Table 7 implies that had there been no growth in mean income between 1988 and 2002, the worsening of the distribution of income would have increased the headcount by 8 percentage points (a rise in poverty of over a fifth). The redistributional component of the decomposition of poverty changes is most marked when considering the interval between the 1988 and 1995 surveys. For the narrower definition of poverty ( $\$ 2$ a day poverty line), the distributional component of the poverty changes is almost fully twice the size of the growth component. This implies that, for the very poor, adverse changes in the distribution of income outweighed the beneficial effects of general economic growth. The only exception to the unfavourable distributional changes is the period 1999-2002 
when the income distribution improves slightly and so would have implied a reduction in poverty even without growth.

\subsection{Sectoral decomposition: the paradox of rising unemployment and falling poverty}

Perhaps the most surprising aspect of our results is that poverty in absolute terms has fallen at the same time as mass unemployment has emerged. Table 8 provides some insight into this paradox, presenting poverty statistics for 1995 and 2002 for households classified according to the economic activity of the household head. Of particular interest is the comparison between households headed by employed workers and those headed by the unemployed. However, the table also reports on those headed by the retired and by those who do not participate in the labour market for other reasons (e.g. attending domestic duties). Given these mutually exclusive groups, it is possible to decompose the overall change in the proportion living in poverty into the effects of changes in poverty within the groups and changes in the size of each group (Ravallion and Huppi, 1991). Specifically, if $\mathrm{P}_{\mathrm{t}}$ is the total poverty indicator at time $\mathrm{t}$ and $\mathrm{P}_{\mathrm{it}}$ the corresponding indicator for those belonging to a group $\mathrm{i}$, then:

$\mathrm{P}_{\mathrm{T}}-\mathrm{P}_{0}=\Sigma\left(\mathrm{P}_{\mathrm{i} T}-\mathrm{P}_{\mathrm{i} 0}\right) \mathrm{n}_{\mathrm{i} 0} \quad$ intra-group effects

$+\Sigma\left(\mathrm{n}_{\mathrm{iT}}-\mathrm{n}_{\mathrm{i} 0}\right) \mathrm{P}_{\mathrm{i} 0} \quad$ inter-group effects

$+\Sigma\left(\mathrm{P}_{\mathrm{iT}}-\mathrm{P}_{\mathrm{i} 0}\right)\left(\mathrm{n}_{\mathrm{iT}}-\mathrm{n}_{\mathrm{i} 0}\right) \quad$ interaction effects

where $\mathrm{n}_{\mathrm{it}}$ is the proportion of the population in group $\mathrm{i}$ at time $\mathrm{t}$. The interaction effects would be positive if people moved into groups where poverty was falling.

The impact of the program of lay-offs in the state sector in the second half of the 1990s is shown in the population shares of the various groups in Table 8. In 1995, only $0.4 \%$ of individuals in the sample lived in households headed by an unemployed worker. In 2002, this percentage had risen to $6.2 \%$. Perhaps even more revealingly, the proportion living in households with employed heads fell from $80 \%$ to $71 \%$. Although one might expect some increase in the proportion living in households with 
retired heads due to an ageing of the population, our figures are consistent with some of the retrenchment in China having taken the form of early retirement rather than unemployment per se.

Other things being equal, the emergence of mass unemployment would be expected to increase poverty. This is born out by the contribution of the population shifts shown in Table 8. For example, Table 8 a uses the "two dollar a day" line. The results imply that the poverty headcount would have increased by 1.3 points, from its 1995 level of $7 \%$. However, this is more than offset by falls in poverty rates within groups. For example, the fall in the headcount among those living in households with employed heads would imply a 4.1 point drop in the poverty headcount. This alone would account for four-fifths of the observed fall in poverty. Moreover, the interaction effects also imply falls in poverty because the groups that have grown in size - those headed by the unemployed and the retired - have also experienced the fastest reduction in poverty. The results are qualitatively similar when using the three dollar a day line, as in Table 8b.

Perhaps the most important reason why the rise in unemployment is not as disastrous as might be thought is because only a minority of households headed by the unemployed are absolutely poor. For example, just $7 \%$ of people in households headed by the unemployed have incomes of less than \$2 per head per day in 2002. This is only a small minority, even if it is substantially above the $2 \%$ headcount for all urban people. If $\$ 3$ a day was used as the poverty line, $22 \%$ of those in households headed by the unemployed would be poor. These figures are all the more remarkable because our poverty rates are measured by income, rather than consumption. Clearly, households with unemployed heads are finding sources of income other than their heads earnings to support themselves. This income is partly earnings from the spouse of the head (or other family members). In this respect, the high rates of female employment in urban China should be acknowledged.

\subsection{The effectiveness of China's social safety network}

The Chinese Government believed that a universal welfare provisional system would assist in allowing it to pursue State sector reforms aimed at enhancing efficiency and 
promoting growth. Such a system would transfer the financial burdens of welfare provision from State enterprises and would pave the way to further retrench State workers in the coming years. However, the decentralised fiscal system could not support a nationwide universal welfare system. Consequently, local - not central governments have become the main players in welfare provision and they are also joined by firms in both State and private sectors.

The CHIP data allows us to identify three kinds of welfare payment: payment made by work units ${ }^{4}$; unemployment insurance (UI); and Minimum Living Standard (MLS hereafter). Payments by work units took the form of hardship relief in 1988 and 1995; and redundancy benefits in 1999 and 2002. Unemployment insurance was begun in 1986 and by 2000 covered about half of all urban workers (Chen, 2001). Minimum Living Standard allowance first launched in Shanghai in 1993 and eventually extended to 667 major cities and 738 county-towns by 2000 (Ministry of Civil Affair 2000). However, despite the large geographic coverage, relatively few people received MLS - only 3 million people in 2000 (Shang and Saunders, 2001).

Table 9 provides some data on these three forms of welfare payments and their impacts. The table first shows the rise of mass unemployment in urban China. In 1995, only $5.55 \%$ households included a member who had been retrenched. This proportion almost quadrupled to $20 \%$ in 1999 and 2002. It is striking that relatively few of these households received any of the three forms of social welfare. In 1995, only $3 \%$ of households with retrenched workers reported receiving Hardship Relief or MLS allowance. The coverage of these schemes greatly expanded during the second half of the 1990s, but by 1999 , only $21 \%$ of households with retrenched workers received income from these sources. By far the most common form of assistance was redundancy payments from work units, which were received by $18 \%$ of households with retrenched workers. The failure of these payments to reach the majority of laidoff workers presumably reflects an inability to pay within failing work units. However, social welfare funded by central and local government did very little to support retrenched workers who were not supported by former work units - both unemployment insurance and MLS allowance reached only an insignificant proportion of households with laid-off workers (1\% and 2\% respectively). By 2002, financial support from work units had dwindled to a trickle as the government 
assumed responsibility for social welfare and required laid-off workers to end their contractual links with their work units. State funded welfare coverage had increased but still reached only a small minority of affected households. Of those households with retrenched workers, only $11 \%$ benefited from unemployment insurance and $8 \%$ from MLS.

To gauge the effectiveness of the Chinese government's effort in fighting poverty, we counterfactually remove all the three anti-poverty measures from household incomes and compute poverty and inequality statistics. Implicitly this makes a number of strong assumptions - for example, that households' gross incomes would not vary if the measures did not exist - but the counterfactual is nonetheless interesting. As might be expected from their low coverage, the programs had essentially no impact on poverty or inequality. However, even in 1999 and 2002, they had only a small effect. Without the income from the programs, the Gini coefficient would have been $0.9 \%$ higher in 1999 and $0.6 \%$ higher in 2002 . The poverty headcount, using a dollar a day poverty line, would have been $0.6 \%$ higher in 1999 and $0.4 \%$ higher in 2002 . These small effects are understandable given the low coverage of the three anti-poverty programs. They indicate that there is a lot of scope for improving government programs against urban poverty. It may be a cause for concern that the rise in the role of the two state-funded anti-poverty schemes between 1999 and 2002 did not fully offset the decline in payments funded by work units.

\section{Patterns of poverty and inequality - multivariate analysis}

We have documented the fall in absolute poverty among urban residents in China from 1988 to 2002. Insights into the changing patterns of poverty can be provided by simple multivariate modelling. Following Appleton (2001), we use three estimation methods. The first simply uses Ordinary Least Squares to model the log of household income per capita. The second uses a probit to model whether the household is poor or not (where poverty is defined as income per capita of less than $\$ 3$ per day for this purpose). The third estimation method is more unconventional: it censors household income per capita at the poverty line (\$3 per day) and uses a tobit to estimate the determinants of the log of this censored income variable. This third method forms abridge between the more usual OLS and probit models - like the probit, it models 
one measure of poverty (the gap between household income and the poverty line), but it does so in a way that produces coefficients comparable to those of the OLS model of income.

Using these three estimation methods, we specify two kinds of model: reduced form models and full models. The reduced form models use a parsimonious set of variables capturing the human capital of the household head, household demographics and provincial dummy variables. The full models augment the reduced form models with dummy variables for the work-related characteristics of the household head specifically, occupation, industrial sector and ownership sector. The reduced form models are interesting because they are likely to provide more comprehensive estimates of the effects of some variables - for example, education may affect income via occupation, so controlling for occupation will underestimate the overall effects. However, the full models are also useful in describing associations between workrelated characteristics and outcomes.

\subsection{Reduced form results - human capital and demographics}

Income differentials have widened over time by a variety by characteristics of the household head. The Table 10 presents some key results from the reduced form models. After 1995 in particular, there is an increase over time in the importance of the education of the household head in raising household income and reducing the likelihood of being in poverty. An extra year's schooling of the head is associated with a $4 \%$ rise in household income per capita in 1988, rising to $8 \%$ in 2002 . Being a member of the Communist Party is also associated with a widening income differential over time - rising from $17 \%$ in 1988 to $36 \%$ in 1999, although it falls back somewhat to $25 \%$ in $2002^{5}$. The sex of the household also increases in importance over time - ceteris paribus, male headed households have 1\% higher income in 1988, a wholly insignificant differential. However, by 2002, the differential has risen to $12 \%$ and is significant at the $1 \%$ level. Figure 3 illustrates these differentials, whose trends largely mirror those obtained by modelling the wages of individual workers in the surveys (Appleton et al., 2005). There are quantitative differences between the differentials in household income and in individual wages, however. Income differentials by the sex of the household head have risen less than wage differentials 
by the sex of workers, because most households include both working men and working women. Conversely, income differentials between households whose heads are CCP members and those whose heads are not have risen more than the CCP wage premium, because CCP members often marry other CCP members. By contrast, the trends in income and wage differentials by education are almost identical, except that wage differentials rose between 1988 and 1995.

Income differentials by age of the household head are also at their most marked in 2002. Figure 4 plots out the quadratic relations between age and income estimated from the OLS models for household income in the four surveys. There was a clear rise in the returns to age between 1988 and 1995 and later between 1999 and 2002. However, the change in the age profile between 1995 and 1999 was different, with households with middle-aged heads enjoying less of an income advantage over those with either young or old heads. Initially, in 1988, there was a distinctly nonmonotonic relationship - the turning point for the quadratic was forty years of age in 1988. Over time, that turning point has risen, until 2002 when it stood at eighty years of age. This implies that in 2002, contrary to the inverse U-relation estimated for 1988, there is a monotonic relation between age and income for most of the range of interest.

Throughout the CHIP surveys, a higher ratio of dependents to working age adults is associated with lower household income, as is a higher absolute number of adults. The coefficients on these two demographic variables fluctuate over time, with the number of adults being more negative in 2002 than 1988.

Most of the results from the OLS income functions carry over to the probit and Tobit poverty functions. If anything, the rise in the returns to education and to membership of the CCP is more marked in the Tobit models - implying a stronger effect among the lower end of the income distribution. For example, between 1988 and 2002, the return to a year of education rises from $4 \%$ in both the OLS and Tobit functions to $10 \%$ in the tobit for 2002 compared to $8 \%$ in the OLS. CCP membership raises income in the tobits for 1999 and 2002 by twice as much as it does in the corresponding OLS income functions. There are also some differences in the effect of the sex of the household head. This never significantly affects the probability of being poor in the 
probits. While coming from a male-headed household does appear to be a significant advantage in the OLS model in 2002, this is not true for the Tobit - although the reverse could be said of 1988 (when it is significant in the Tobit but not the OLS).

\subsection{Full models - the effect of job-characteristics}

We now turn to the "full models" which include various characteristics of the household head's job - namely, occupation, ownership and industrial sector. Including these characteristics tends to reduce the estimated effects of some of the other characteristics of the head - such as their education and CCP membership. However, the trends discussed above remain robust to inclusion of job-characteristics. We begin by discussing the effects of job characteristics on the OLS models of household income.

As Table 11 shows, ceteris paribus, those employed in foreign firms had significantly higher household incomes while those in private enterprises had significantly lower income. However, these differentials narrowed between 1988 and 2002. Conversely, the income gap between households whose heads worked in urban collectives widened over time, so that by 2002 , this was appeared the least remunerative ownership sector to work in.

Income differentials between household heads who were manual workers tended to widen over time. For example, professionals and clerks more than doubled their apparent advantage over manual workers between 1988 and 2002. Households whose heads were unemployed due to retrenchment had lower incomes than those with heads working in manual jobs. However, the extent of the differential fell markedly from 1995 onwards. In 1995, the differential was $-46 \%$, significant at the $1 \%$ level. This differential fell to $-25 \%$ in 1999 and $-17 \%$ in 2002, significant only at the $10 \%$ level. These results suggest that over time, households with unemployed heads were more able to compensate for the loss in earnings by other means - perhaps increased welfare payments or, in 2002 when unemployment was falling, by the earnings of other members. The relative income of households whose heads were retired was also more favourable in 2002 than in earlier years: the model predicts that they have 39\% higher 
income than households with heads in manual work, while models for earlier years predict only insignificant differences.

There has been a major change in household income differentials by industrial sector. In 1988, there were few significant differences, ceteris paribus, in household income according to the industrial sector of the household head. The default sector, manufacturing, appeared to pay no different from most other sectors and significantly more than government administration. Urban households whose heads worked in mining and agriculture, as well as the wholesale and retail sectors had higher incomes, ceteris paribus, than households whose heads worked in manufacturing. By 2002, these differentials had all been reversed. Mining and agriculture were associated with the lowest household incomes, followed by construction, retail and wholesale services and manufacturing. Heads who worked in other sectors had significantly higher household incomes, for example, those working in government administration had $15 \%$ higher household incomes than those in manufacturing. These sectoral changes correspond to those estimated for individual wages, using the same CHIP surveys (Appleton et al., 2005).

For brevity, we do not report the Tobit models for the full specification, preferring to concentrate instead on the probits for whether a household is not poor. There are fewer pronounced changes over time in the coefficients on job characteristics in the probits for households being non-poor than in the OLS income models. For example, the coefficients on ownership sector in the probit do not shift markedly. Among the occupational dummies, the main change is that, by 2002 , households headed by clerks are significantly less likely to be poor, ceteris paribus, whereas in 1988, there was no such effect. The dummies for the industrial sector in which the head works do change substantially in size and sometimes sign, in line with what one might expect from the OLS results, but remain largely insignificant in both 1988 and 2002.

\section{Conclusion}

China's high economic growth is perhaps the most significant economic development in the world over the last two decades. Much of its significance has been in the improvement of rural livelihoods. Nonetheless, it also has important impacts on urban 
China - areas that accounted for $39 \%$ of its population (in 2002). There has been a growing unease that this growth has been unequally shared and has led to the rise of a "new urban poverty". Sceptics concede that economic efficiency and growth may have been promoted by urban reforms involving a reduction in subsidies for urban households and retrenchment of excess employees in State Owned Enterprises. However, there is concern that these same reforms may have increased urban poverty, by reducing transfers to low income households and inducing mass unemployment.

In this paper, we have focussed on the real incomes of urban residents at the lower end of the income distribution in urban areas. Using CHIP surveys which include state subsidies and transfers in their measurement of household income, we have shown that living standards rose across the distribution of income from 1988 to 2002. This truth has been masked by conventional analysis of urban poverty in China which defines only a very small minority of the urban population - for example, the $1 \%$ of so defined as poor by using a "dollar a day" poverty line. We find evidence that the withdrawal of subsidies between 1988 and 1995 lowered the real income of the poorest in urban areas. However, this was subsequently outweighed by growth in other sources of income. Perhaps most surprisingly, we find that - despite the rise of mass unemployment after 1995 - absolute poverty continued to fall, irrespective of where the poverty line was set. This implies that the concern that absolute poverty has risen during urban reform is misplaced. State-funded anti-poverty programs have expanded in urban China during this period, but still had very limited coverage and made little impact on poverty or inequality in this period.

As well as changes in the level of urban poverty, the last twenty years have seen changes in patterns of income and poverty. Multivariate analysis of household income reveals that differentials by education, sex, age and Communist party membership have tended to widen from 1988 to 2002 . Tobit analysis implies that these widening differentials apply as much to the lower end of the income distribution as much as, and perhaps more than, the top. Furthermore, there appears to have been a reduction in the protection afforded to the kinds of jobs previously favoured under the planning period - manual occupations in the primary and manufacturing sectors. These factors help to explain the rise in urban inequality since 1988. However, an important insight of the CHIP surveys is that the rise in overall income inequality was largely confined 
to the 1988-95 interval. Neither the 1999 survey, nor the 2002 one, show a continuation of the rise in urban inequality after 1995.

From our analysis, urban China is growing out of poverty, at least when defined in absolute terms. However, there are several important caveats to this conclusion. First, our results apply only to registered urban residents, since most migrants are excluded from official surveys. Second, we do find that some inequalities have widened and relative poverty has increased. Finally, we refer back to our findings on the ineffectiveness of government anti-poverty programs in reducing urban poverty. The government in China might be said to have gambled by heavily relying on economic growth to resolve many social problems including poverty reduction. One wonders what will happen if growth stops or there is a major recession? 


\section{References}

Appleton, Simon (2001), "The rich are just like us, only richer" Poverty functions or consumption functions? Evidence from Uganda" Journal of African Economies, 10(4): 433-469.

Appleton, Simon, John Knight, Lina Song and Qingjie Xia (2002) "Labour Retrenchment in China: Determinants and Consequences", China Economic Review, 13(2-3): 252-275.

Appleton, Simon, Lina Song and Qingjie Xia (2005) "Has China crossed the river? The evolution of the wage structure in urban China" with Lina Song and Qingjie Xia, Journal of Comparative Economics, 33(5): 644-663, 2005.

Chen, J. (eds) (2001). China's Social Security Development Report: 1997-2001 (Zhong Guo She Hui Bao Zhang Fa Zhan Bao Gao: 1997-2001). Beijing: Social Sciences Literature Press (She Hui Ke Xue Chu Ban She).

Chen, S. and Y. Wang (2001), "China's growth and poverty reduction: recent trends between 1990 and 1999", World Bank Policy Research Working Paper 2651.

Datt, G. and Ravallion, M. (1992). "Growth and Redistribution Components of Changes in Poverty Measures: A Decomposition with Applications to Brazil and India in the 1980s", Journal of Development Economics 38(2): 275-295.

Dollar, David and Aart Kray (2000) "Growth is good for the Poor", World Bank Working Paper, available to download from www.worldbank.org/research.

Fang, Cheng, Xiaobo Zhang and Shenggen Fan (2002), "Emergence of urban poverty and inequality in China: evidence from household survey" China Economic Review 12: 430-443.

Fields, Gary (2001) Distribution and Development, Cambridge, MA: Russell Sage Publishers.

Fishlow, A. (1972), "Brazilian size distribution of income" American Economic Review Papers and Proceedings 391-402.

Foster, J., J. Greer and E. Thorbecke (1984), "A Class of Decomposable Poverty Indices", Econometrica, Vol. 52, pp. 761-765.

Khan, Azizur (1996) The impact of recent macroeconomic and sectoral changes on the poor and women in China New Delhi: ILO.

---- (1998) "Poverty in China in the era of globalization", Issues in Development Discussion Paper 22 International Labour Organisation: Geneva.

Khan, A.R., K.Griffin, C. Riskin and Zhao Renwei (1993) "Household income and its definition in China", paper 1 of Griffin, Keith and Zhao Renwei (eds.), The Distribution of Income in China Macmillan: London. 
Khan, A. and C. Riskin (2001) Inequality and poverty in China in the age of globalization Oxford University Press: New York.

Knight, John and Lina Song (1999) The rural-urban divide: economic disparities and interactions in China, Oxford University Press: Oxford.

Knight, John and Lina Song (2005) Towards a labour market in China, Oxford University Press: Oxford

Kuznets, Simon (1955), "Economic growth and income inequality" American Economic Review 45(1): 1-28.

Meng, Xin, Gregory, Robert and Wang, Youjuan (2005), "Poverty, Inequality, and Growth in Urban China, 1986-2000", Journal of Comparative Economics 33(4): 710729.

Park, Albert, Yang Du and Sangui Wang (2004), "Is migration helping China's poor?", paper presented at a conference on "Poverty, Inequality, Labour Market and Welfare Reform in China”, 25-27 August, Australian National University: Canberra.

Ravallion, M. (1992) "Poverty comparisons: a guide to concepts and methods", Living Standards Measurement Paper No. 88, World Bank: Washington DC.

Ravallion, M. and S. Chen (2004), "China's (Uneven) Progress against Poverty", paper presented at a conference on "Poverty, Inequality, Labour Market and Welfare Reform in China", 25-27 August, Australian National University: Canberra.

Ravallion, Martin and Monica Huppi (1991), "Measuring changes in poverty: a methodological case study of Indonesia during an adjustment period", World Bank Economic Review 5(1): 57-82.

Riskin, Carl, Zhao Renwei, and Li Shi (eds.) (2001) China's Retreat from Equality: Income Distribution and Economic Transition M.E. Sharpe: Armonk, N.Y.

Shang, Xiaoyuan and Saunders, Peter (2001), "Social Security Reform in China's Transition to a Market Economy", Social Policy and Administration 35 (3), 274-289.

Song, Lina and Appleton, Simon (2006), "Inequality and Instability: An Empirical Investigation into Social Discontent in Urban China", University of Nottingham: mimeo

Wang QB, Shi GM and Zheng Y (2002) "Changes in income inequality and welfare under economic transition: evidence from urban China" Applied Economics Letters 9 (15): $989-991$.

Wu. F. (2004), "Urban poverty and marginalization under market transition: the case of Chinese cities" International Journal of Urban and Regional Research, 28(2): 401423. 
Wong, Linda (1998), Marginalization and Social Welfare in China, Routledge: London.

World Bank (2001), World Development Report 2000/01: Attacking Poverty Oxford University Press: New York. 
Table 1: Compilation of estimates of poverty rates in urban China, 1988 onwards

\begin{tabular}{|c|c|c|c|c|c|c|c|c|c|c|c|c|c|}
\hline & Khan (199 & & $\begin{array}{l}\text { Khan } \\
(1996)\end{array}$ & $\begin{array}{l}\text { Meng, Gre } \\
\text { Wang (200 }\end{array}$ & $\begin{array}{l}\text { egory and } \\
\text { 04) }\end{array}$ & Fang et al. & . (2002) & Chen and & Wang (200 & & $\begin{array}{l}\text { Ravallion } \\
\text { and Chen }\end{array}$ & $\begin{array}{l}\text { Appleton } \\
\text { (this pape }\end{array}$ & $\begin{array}{l}\text { and Song } \\
\text { r) }\end{array}$ \\
\hline $\begin{array}{r}\text { Poverty } \\
\text { line } \\
\text { anchor }\end{array}$ & $2150 \mathrm{cal}$. & 2100 cal. & $2150 \mathrm{cal}$. & $\begin{array}{l}2100 \text { cal. } \\
\text { (upper) } \\
\text { but varies }\end{array}$ & $\begin{array}{l}2100 \text { cal. } \\
\text { (lower) } \\
\text { but } \\
\text { varies }\end{array}$ & $\$ 1$ a day & $\$ 1.5$ /day & $\$ 1$ a day & $\$ 1.5$ /day & $\$ 2$ a day & 2100 cal. & $\$ 2$ a day & $\$ 3$ a day \\
\hline 1988 & $8.00 \%$ & $2.70 \%$ & & $2.63 \%$ & $1.50 \%$ & & & & & & $2.07 \%$ & $7.33 \%$ & $36.36 \%$ \\
\hline 1989 & & & $7.42 \%$ & $2.62 \%$ & $1.59 \%$ & & & & & & $7.05 \%$ & & \\
\hline 1990 & & & $7.39 \%$ & $1.91 \%$ & $0.97 \%$ & & & $1.00 \%$ & $8.60 \%$ & $20.70 \%$ & $2.58 \%$ & & \\
\hline 1991 & & & $4.73 \%$ & $2.49 \%$ & $1.29 \%$ & & & & & & $1.66 \%$ & & \\
\hline 1992 & & & & $3.62 \%$ & $1.72 \%$ & $2.09 \%$ & $13.74 \%$ & $0.80 \%$ & $3.90 \%$ & $13.20 \%$ & $1.13 \%$ & & \\
\hline 1993 & & & & $5.33 \%$ & $2.30 \%$ & & & $0.70 \%$ & $4.20 \%$ & $13.80 \%$ & $1.01 \%$ & & \\
\hline 1994 & & & $5.90 \%$ & $5.11 \%$ & $2.63 \%$ & $2.73 \%$ & $13.18 \%$ & $0.90 \%$ & $4.60 \%$ & $13.50 \%$ & $1.19 \%$ & & \\
\hline 1995 & $8.80 \%$ & $4.00 \%$ & & $5.35 \%$ & $2.57 \%$ & $1.65 \%$ & $10.27 \%$ & $0.60 \%$ & $3.00 \%$ & $9.70 \%$ & $0.85 \%$ & $7.00 \%$ & $23.81 \%$ \\
\hline 1996 & & & & $4.94 \%$ & $2.28 \%$ & $1.69 \%$ & $8.41 \%$ & $0.50 \%$ & $2.60 \%$ & $9.30 \%$ & $0.61 \%$ & & \\
\hline 1997 & & & & $5.28 \%$ & $2.48 \%$ & $2.00 \%$ & $9.21 \%$ & $0.50 \%$ & $2.70 \%$ & $9.10 \%$ & $0.70 \%$ & & \\
\hline 1998 & & & & $4.83 \%$ & $1.85 \%$ & $2.06 \%$ & $8.86 \%$ & $1.00 \%$ & $3.40 \%$ & $9.00 \%$ & $1.16 \%$ & & \\
\hline 1999 & & & & $4.21 \%$ & $1.70 \%$ & & & $0.50 \%$ & $2.20 \%$ & $6.80 \%$ & $0.57 \%$ & $3.66 \%$ & $12.39 \%$ \\
\hline 2000 & & & & $3.97 \%$ & $1.71 \%$ & & & & & & $0.63 \%$ & & \\
\hline 2001 & & & & & & & & & & & $0.50 \%$ & & \\
\hline 2002 & & & & & & & & & & & $0.54 \%$ & $2.88 \%$ & $8.52 \%$ \\
\hline $\begin{array}{l}\text { Data } \\
\text { source }\end{array}$ & CHIP & CHIP & $\begin{array}{l}\text { NBS } \\
\text { grouped }\end{array}$ & NBS & NBS & \begin{tabular}{|l|} 
Subset of \\
NBS
\end{tabular} & $\begin{array}{l}\text { Subset of } \\
\text { NBS }\end{array}$ & \begin{tabular}{|l} 
NBS \\
grouped
\end{tabular} & $\begin{array}{l}\text { NBS } \\
\text { grouped }\end{array}$ & \begin{tabular}{|l} 
NBS \\
grouped
\end{tabular} & \begin{tabular}{|l}
$\begin{array}{l}\text { NBS } \\
\text { grouped }\end{array}$ \\
\end{tabular} & CHIP & CHIP \\
\hline
\end{tabular}

Notes: (1) The most common source of data is the official NBS surveys, although typically researchers only have access to the grouped tabulations. The CHIP surveys are used in the original analysis in this paper and are discussed in the text. (2) Poverty lines are typically absolute, either working as multiples of \$1 a day (Purchasing Power Parity adjusted) or calculating the cost of obtaining a certain amount of calories per person per day. Meng et al (2005) re-estimated their poverty line for each year of data. 
Table 2: Basic information on urban household income per capita, Household Income Project Surveys

\begin{tabular}{|l|l|l|l|l|}
\hline & $\mathbf{1 9 8 8}$ & $\mathbf{1 9 9 5}$ & $\mathbf{1 9 9 9}$ & $\mathbf{2 0 0 2}$ \\
\hline Mean income per capita & 4820 & 6673 & 8771 & 9853 \\
\hline Median income per capita & 4268 & 5365 & 7180 & 8365 \\
\hline \% of income from: & & & & \\
\hline 1. Earnings of working members & $43.2 \%$ & $59.4 \%$ & $51.7 \%$ & $60.2 \%$ \\
\hline 2. Income of retired & $8.0 \%$ & $13.5 \%$ & $18.3 \%$ & $16.7 \%$ \\
\hline $\begin{array}{l}\text { 3. Income of other non-working } \\
\text { members }\end{array}$ & $0.5 \%$ & 0 & 0 & 0 \\
\hline $\begin{array}{l}\text { 4. Income from private or individual } \\
\text { enterprises }\end{array}$ & $0.7 \%$ & $0.5 \%$ & $1.8 \%$ & $2.7 \%$ \\
\hline 5. Income from property & $0.5 \%$ & $1.3 \%$ & $0.9 \%$ & $0.6 \%$ \\
\hline $\begin{array}{l}\text { 6. Miscellaneous income (including } \\
\text { private transfers and special income) }\end{array}$ & $4.45 \%$ & $3.4 \%$ & $2.2 \%$ & $3.1 \%$ \\
\hline $\begin{array}{l}\text { 7. Subsidies less taxes (except housing } \\
\text { subsidy and coupons) and income in } \\
\text { kind }\end{array}$ & $15.3 \%$ & $1.2 \%$ & $0.2 \%$ & $0.2 \%$ \\
\hline 8. Ration coupon subsidy & $5.2 \%$ & 0 & 0 & 0 \\
\hline 9. Housing subsidy & $18.4 \%$ & $10.1 \%$ & $6.5 \%$ & $2.8 \%$ \\
\hline $\begin{array}{l}\text { 10. Rental value of owner occupied } \\
\text { housing }\end{array}$ & $3.7 \%$ & $10.8 \%$ & $18.5 \%$ & $13.9 \%$ \\
\hline Number of observations & 9005 & 6929 & 3998 & 6835 \\
\hline
\end{tabular}

Note: yuan per year, 2002 constant prices.

This and subsequent tables are based on authors' calculations from the Household Income Project surveys of the Institute of Economics, Chinese Academy of Social Sciences. 
Table 3: Growth rates of urban household income, CHIP and NBS data compared.

\begin{tabular}{|l|l|l|}
\hline & $\begin{array}{l}\text { Chinese household income } \\
\text { project (CHIP) }\end{array}$ & $\begin{array}{l}\text { State Statistical Bureau } \\
\text { (NBS) }\end{array}$ \\
\hline $1988-1995$ & $4.65 \%$ & $6.63 \%$ \\
\hline $1995-1999$ & $6.83 \%$ & $5.42 \%$ \\
\hline $1999-2002$ & $3.88 \%$ & $8.98 \%$ \\
\hline $1988-2002$ & $5.11 \%$ & $6.79 \%$ \\
\hline
\end{tabular}

Table 4: Urban household income per capita by decile, Household Income Project Surveys

\begin{tabular}{|l|r|r|r|r|r|}
\hline & 1988 & & 1995 & 1999 & 2002 \\
\hline $10^{\text {th }}$ & 2705 & 2855 & 3502 & 4024 \\
\hline $20^{\text {th }}$ & 3180 & 3542 & 4504 & 5134 \\
\hline $30^{\text {th }}$ & 3553 & 4142 & 5400 & 6203 \\
\hline $40^{\text {th }}$ & 3902 & 4709 & 6284 & 7271 \\
\hline $50^{\text {th }}$ & 4268 & 5365 & 7180 & 8365 \\
\hline $60^{\text {th }}$ & 4663 & 6080 & 8159 & 9535 \\
\hline $70^{\text {th }}$ & 5186 & 7040 & 9540 & 11035 \\
\hline $80^{\text {th }}$ & 6019 & 8545 & 11506 & 13380 \\
\hline $90^{\text {th }}$ & 7477 & 11489 & 15030 & 17211 \\
\hline
\end{tabular}

Note: RMB Yuan per year, 2002 constant prices

Table 5: Inequality in urban household income per capita, 1988-2002

\begin{tabular}{|l|l|l|l|l|}
\hline & $\mathbf{1 9 8 8}$ & $\mathbf{1 9 9 5}$ & $\mathbf{1 9 9 9}$ & $\mathbf{2 0 0 2}$ \\
\hline Gini coefficient & 0.235 & 0.328 & 0.331 & 0.318 \\
\hline $\begin{array}{l}\text { Atkinson index ( with 1.5 } \\
\text { inequality aversion) }\end{array}$ & 0.123 & 0.238 & 0.244 & 0.225 \\
\hline $\begin{array}{l}\text { Generalised entropy (1) or Theil's } \\
\text { T index }\end{array}$ & 0.100 & 0.223 & 0.262 & 0.172 \\
\hline $\begin{array}{l}\text { Generalised entropy (2) or Theil's } \\
\text { L index }\end{array}$ & 0.091 & 0.184 & 0.193 & 0.170 \\
\hline
\end{tabular}


Table 6: Urban poverty indices, with $\$ 2$ and $\$ 3$ a day poverty lines, 1988-2002

\begin{tabular}{|l|l|l|l|l|}
\hline & 1988 & 1995 & 1999 & 2002 \\
\hline With \$2 a day poverty line & & & & \\
\hline Head count, P0 & $7.33 \%$ & $7.00 \%$ & $3.66 \%$ & $2.08 \%$ \\
\hline Poverty gap, P1 & $1.17 \%$ & $1.64 \%$ & $0.92 \%$ & $0.38 \%$ \\
\hline Squared poverty gap, P2 & $0.31 \%$ & $0.62 \%$ & $0.38 \%$ & $0.17 \%$ \\
\hline With \$3 a day poverty line & & & & \\
\hline Head count, P0 & $36.36 \%$ & $23.81 \%$ & $12.39 \%$ & $8.52 \%$ \\
\hline Poverty gap, P1 & $7.50 \%$ & $5.88 \%$ & $3.12 \%$ & $1.26 \%$ \\
\hline Squared poverty gap, P2 & $2.34 \%$ & $2.28 \%$ & $1.26 \%$ & $0.72 \%$ \\
\hline $\begin{array}{l}\text { With half median income poverty } \\
\text { line }\end{array}$ & & & & \\
\hline Head count, P0 & $3.8 \%$ & $9.3 \%$ & $11.8 \%$ & $12.8 \%$ \\
\hline Poverty gap, P1 & $0.59 \%$ & $2.25 \%$ & $3.00 \%$ & $3.08 \%$ \\
\hline Squared poverty gap, P2 & $0.15 \%$ & $0.86 \%$ & $1.21 \%$ & $0.12 \%$ \\
\hline
\end{tabular}

Note: Poverty lines are in constant 1985 PPP dollars. One 1985 PPP dollar corresponds to 1212 yuan in 2002 prices.

Table 7: Decomposition of urban poverty changes into growth and redistributional components (headcount poverty index)

\begin{tabular}{|l|l|l|l|l|}
\hline & $\begin{array}{l}\text { Growth } \\
\text { component }\end{array}$ & $\begin{array}{l}\text { Redistribution } \\
\text { component }\end{array}$ & Residual & $\begin{array}{l}\text { Total change } \\
\text { in poverty }\end{array}$ \\
\hline $\begin{array}{l}\text { (a) \$2 a day } \\
\text { poverty line }\end{array}$ & & & & \\
\hline $1988-1995$ & $-6.02 \%$ & $11.64 \%$ & $-5.95 \%$ & $-0.33 \%$ \\
\hline $1995-1999$ & $-4.09 \%$ & $1.43 \%$ & $-0.67 \%$ & $-3.34 \%$ \\
\hline $1999-2002$ & $-0.96 \%$ & $-0.35 \%$ & $-0.28 \%$ & $-1.58 \%$ \\
\hline $1988-2002$ & $-7.19 \%$ & $13.05 \%$ & $-11.11 \%$ & $-5.25 \%$ \\
\hline $\begin{array}{l}\text { (b) \$3 a day } \\
\text { poverty line }\end{array}$ & & & & \\
\hline $1988-1995$ & $-25.87 \%$ & $12.01 \%$ & $1.32 \%$ & $-12.54 \%$ \\
\hline $1995-1999$ & $-13.42 \%$ & $1.25 \%$ & $0.74 \%$ & $-11.42 \%$ \\
\hline $1999-2002$ & $-3.35 \%$ & $-0.47 \%$ & $-0.04 \%$ & $-3.87 \%$ \\
\hline $1988-2002$ & $-34.95 \%$ & $7.96 \%$ & $-0.88 \%$ & $-27.83 \%$ \\
\hline
\end{tabular}



Table 8: Decomposition of urban poverty changes by employment status of household head, 1995-2000

a) $\$ 2$ a day poverty line

\begin{tabular}{|l|r|r|r|r|r|r|r|}
\hline & \multicolumn{2}{|c|}{1995} & \multicolumn{2}{c|}{2002} & \multicolumn{3}{c|}{ Contribution of } \\
\hline & $\begin{array}{c}\text { Population } \\
\text { Share }\end{array}$ & $\begin{array}{c}\text { Poverty } \\
\text { headcount }\end{array}$ & $\begin{array}{l}\text { Population } \\
\text { Share }\end{array}$ & $\begin{array}{c}\text { Poverty } \\
\text { headcount }\end{array}$ & $\begin{array}{c}\text { Population } \\
\text { shifts }\end{array}$ & $\begin{array}{c}\text { Intra-group } \\
\text { changes }\end{array}$ & Interaction \\
\hline Employed & 80.31 & 7.02 & 71.04 & 1.86 & -0.65 & -4.14 & 0.48 \\
\hline Unemployed & 0.4 & 31.03 & 6.19 & 6.97 & 1.80 & -0.10 & -1.39 \\
\hline Retired & 18.37 & 5.85 & 22.04 & 1.17 & 0.21 & -0.86 & -0.17 \\
\hline $\begin{array}{l}\text { Other non- } \\
\text { participants }\end{array}$ & 0.93 & 17.91 & 0.73 & 9.33 & -0.04 & -0.08 & 0.02 \\
\hline Sum & 100 & 7.00 & 100 & 2.08 & 1.32 & -5.18 & -1.07 \\
\hline
\end{tabular}

b) $\$ 3$ a day poverty line

\begin{tabular}{|l|r|r|r|r|r|r|r|}
\hline & \multicolumn{1}{|l}{1995} & \multicolumn{2}{l|}{ lon2 } & \multicolumn{3}{c|}{ Contribution of } \\
\hline & $\begin{array}{l}\text { Population } \\
\text { Share }\end{array}$ & $\begin{array}{c}\text { Poverty } \\
\text { headcount }\end{array}$ & $\begin{array}{c}\text { Population } \\
\text { Share }\end{array}$ & $\begin{array}{c}\text { Poverty } \\
\text { headcount }\end{array}$ & $\begin{array}{c}\text { Population } \\
\text { shifts }\end{array}$ & $\begin{array}{c}\text { Intra-group } \\
\text { changes }\end{array}$ & Interaction \\
\hline Employed & 80.31 & 24.07 & 71.04 & 7.83 & -2.24 & -13.04 & 1.51 \\
\hline Unemployed & 0.4 & 50.58 & 6.19 & 21.85 & 2.92 & -0.11 & -1.66 \\
\hline Retired & 18.37 & 21.46 & 22.04 & 6.36 & 0.79 & -2.77 & -0.55 \\
\hline $\begin{array}{l}\text { Other non- } \\
\text { participants }\end{array}$ & 0.93 & 36.32 & 0.73 & 28.67 & -0.07 & -0.07 & 0.02 \\
\hline Sum & 100 & 23.81 & 100 & 8.52 & 1.41 & -16.00 & -0.70 \\
\hline
\end{tabular}

Notes: all numbers are percentages. Poverty lines defined in \$PPP 1985 prices. 
Table 9: The Impact of Social Welfare Payments on Poverty and Inequality

\begin{tabular}{|l|c|c|c|}
\hline & 1995 & 1999 & 2002 \\
\hline $\begin{array}{l}\text { Proportion of households with retrenched } \\
\text { workers }\end{array}$ & $5.55 \%$ & $20.38 \%$ & $20.12 \%$ \\
\hline $\begin{array}{l}\text { Proportion of households with retrenched } \\
\text { being helped by various anti-poverty } \\
\text { measures }\end{array}$ & $2.86 \%$ & $21.18 \%$ & $18.04 \%$ \\
\hline (1) by work unit & $2.34 \%$ & $18.48 \%$ & $1.96 \%$ \\
\hline (2) by unemployment insurance & n.a. & $1.10 \%$ & $10.91 \%$ \\
\hline (3) by low income allowance & $0.52 \%$ & $2.33 \%$ & $8.22 \%$ \\
\hline Actual gini coefficient & 0.3277 & 0.3310 & 0.3181 \\
\hline $\begin{array}{l}\text { Gini coefficient excluding anti-poverty } \\
\text { measures }\end{array}$ & 0.3276 & 0.3341 & 0.3200 \\
\hline Actual P0 (\$3 poverty line) & $23.81 \%$ & $12.39 \%$ & $8.54 \%$ \\
\hline P0 excluding anti-poverty measures & $23.83 \%$ & $12.96 \%$ & $8.93 \%$ \\
\hline $\begin{array}{l}\text { Total reduction in P0 (\$3 poverty line) from } \\
\text { anti-poverty measures }\end{array}$ & $0.02 \%$ & $0.57 \%$ & $0.39 \%$ \\
\hline (1) by work unit & $0.00 \%$ & $0.41 \%$ & $0.02 \%$ \\
\hline (2) by unemployment insurance & n.a. & $0.10 \%$ & $0.18 \%$ \\
\hline (3) by low income allowance & $0.02 \%$ & $0.06 \%$ & $0.19 \%$ \\
\hline
\end{tabular}

Table 10: Reduced form determinants of income and poverty

\begin{tabular}{|c|c|c|c|c|c|}
\hline & $\begin{array}{l}\text { Dependent variable } \\
\text { (estimation method) }\end{array}$ & 1988 & 1995 & 1999 & 2002 \\
\hline \multirow[t]{3}{*}{ Head's schooling (years) } & Income (OLS) & $0.04 * * *$ & $0.04 * * *$ & $0.06 * * *$ & $0.08 * * *$ \\
\hline & Income gap (Tobit) & $0.04 * * *$ & $0.06 * * *$ & $0.10 * * *$ & $0.10 * * *$ \\
\hline & Non-poor (Probit) & $0.16 * * *$ & $0.11 * * *$ & $0.17 * * *$ & $0.19 * * *$ \\
\hline \multirow[t]{3}{*}{ Head is CP member } & Income (OLS) & $0.16 * * *$ & $0.20 * * *$ & $0.31 * * *$ & $0.22 * * *$ \\
\hline & Income gap (Tobit) & $0.17 * * *$ & $0.35 * * *$ & $0.65 * * *$ & $0.48 * * *$ \\
\hline & Non-poor (Probit) & $0.60 * * *$ & $0.69 * * *$ & $1.07 * * *$ & $0.83 * * *$ \\
\hline \multirow[t]{3}{*}{ Male-headed } & Income (OLS) & 0.01 & 0.04 & 0.06 & $0.11 * * *$ \\
\hline & Income gap (Tobit) & $0.06 * *$ & 0.06 & $0.23 *$ & -0.05 \\
\hline & Non-poor (Probit) & 0.19 & -0.01 & 0.44 & 0.01 \\
\hline \multirow[t]{3}{*}{ Dependency ratio } & Income (OLS) & $-1.18 * * *$ & $-1.25 * * *$ & $-1.01 * * *$ & $-1.11 * * *$ \\
\hline & Income gap (Tobit) & $-1.24 * * *$ & $-1.46 * * *$ & $-0.96 * * *$ & $-1.17 * * *$ \\
\hline & Non-poor (Probit) & $-5.04 * * *$ & $-3.02 * * *$ & $-1.86 * * *$ & $-2.18 * * *$ \\
\hline \multirow[t]{3}{*}{ Number of adults (log) } & Income (OLS) & $-0.31 * * *$ & $-0.46 * * *$ & $-0.38 * * *$ & $-0.41 * * *$ \\
\hline & Income gap (Tobit) & $-0.29 * * *$ & $-0.55 * * *$ & $-0.31 * * *$ & $-0.43 * * *$ \\
\hline & Non-poor (Probit) & $-1.27 * * *$ & $-1.20 * * *$ & $-0.59 * * *$ & $-0.84 * * *$ \\
\hline Number of observations & & 8993 & 6928 & 3998 & 6835 \\
\hline $\begin{array}{l}\text { Number poor } \\
\text { (income }<\$ 3 \text { per day) }\end{array}$ & & $\begin{array}{l}2911 \\
(32.4 \%)\end{array}$ & $\begin{array}{l}1488 \\
(21.5 \%)\end{array}$ & $\begin{array}{l}445 \\
(11.1 \%)\end{array}$ & $\begin{array}{l}505 \\
(7.4 \%) \\
\end{array}$ \\
\hline
\end{tabular}

Notes:

(1) $* * *$ denotes statistical significance at the $1 \%$ level; $* *$ at $5 \%$ and $*$ at $10 \%$ levels.

(2) Dependent variables: income $=\log$ of real income per capita;

(3) Income gap $=\log$ of real income per capita; censored at $\$ 3$ per day

(4) Non-poor $=1$ if real income per capita above $\$ 3$ per day

(5) Also included in models but not reported are provincial dummies and quadratics for age of household head. 
Table 11: Effects of job characteristics on income and poverty

\begin{tabular}{|c|c|c|c|c|c|c|c|c|}
\hline & \multicolumn{2}{|c|}{1988} & \multicolumn{2}{|c|}{1995} & \multicolumn{2}{|c|}{1999} & \multicolumn{2}{|c|}{2002} \\
\hline & Income (OLS) & $\begin{array}{l}\text { Non-poor } \\
\text { (Probit) }\end{array}$ & Income (OLS) & $\begin{array}{l}\text { Non-poor } \\
\text { (Probit) }\end{array}$ & Income (OLS) & $\begin{array}{l}\text { Non-poor } \\
\text { (Probit) }\end{array}$ & Income (OLS) & $\begin{array}{l}\text { Non-poor } \\
\text { (Probit) }\end{array}$ \\
\hline \multicolumn{9}{|c|}{ Ownership of head's place of work (State owned enterprise as default) : } \\
\hline Urban collective & $-0.09 * * *$ & $-0.52 * * *$ & $-0.16 * * *$ & $-0.48 * * *$ & $-0.17 * * *$ & $-0.44 * * *$ & $-0.20 * * *$ & $-0.45 * * *$ \\
\hline Private & $-0.22 * * *$ & -0.45 & $-0.41 * * *$ & $-1.22 * * *$ & -0.05 & -0.07 & $-0.14 * * *$ & $-0.41 * * *$ \\
\hline Foreign & $0.40 * * *$ & 1.11 & $0.21 * * *$ & 0.66 & $0.31 * * *$ & 0.20 & $0.17 * * *$ & 0.43 \\
\hline \multicolumn{9}{|c|}{ Occupation of head (manual workers as default): } \\
\hline $\begin{array}{r}\text { Private business } \\
\text { owner }\end{array}$ & 0.01 & $-0.48^{*}$ & $0.12 *$ & 0.33 & $0.33 * * *$ & 0.08 & $0.10^{* * *}$ & 0.07 \\
\hline Professional & $0.07 * * *$ & $0.40 * * *$ & $0.19 * * *$ & $0.69 * * *$ & $0.24 * * *$ & $0.53 * * *$ & $0.17 * * *$ & $0.70 * * *$ \\
\hline Administrator & $0.15 * * *$ & $0.72 * * *$ & $0.26 * * *$ & $0.78 * * *$ & $0.26 * * *$ & 0.17 & $0.22 * * *$ & $0.69 * * *$ \\
\hline Clerk & $0.05 * * *$ & 0.10 & $0.07 * * *$ & $0.13 *$ & $0.17 * * *$ & 0.25 & $0.12 * * *$ & $0.51 * * *$ \\
\hline Retrenched & $-0.23 *$ & $-0.71 * * *$ & $-0.61 * * *$ & $-1.41 * * *$ & $-0.29 *$ & $-1.73 * * *$ & $-0.19 *$ & $-0.97 *$ \\
\hline Retired & 0.12 & $0.80 * * *$ & 0.08 & 0.17 & -0.06 & -0.24 & $0.33 * * *$ & $1.08 * *$ \\
\hline $\begin{array}{r}\text { Other Non-labour } \\
\text { participation }\end{array}$ & $-0.19 * *$ & $-0.94 *$ & $-0.08 * * *$ & 0.11 & -0.03 & $-0.88 *$ & $-0.11 * * *$ & -0.82 \\
\hline \multicolumn{9}{|c|}{ Industrial sector head works in (manufacturing as default): } \\
\hline Mining/agriculture & $0.04 * *$ & $0.31 * * *$ & 0.06 & 0.19 & -0.04 & -0.18 & $-0.10 *$ & -0.22 \\
\hline Construction & 0.00 & -0.03 & 0.00 & $-0.27 *$ & $0.10^{* * *}$ & 0.30 & -0.06 & $-0.47 *$ \\
\hline $\begin{array}{r}\text { Transportation and } \\
\text { communication }\end{array}$ & 0.02 & 0.01 & 0.04 & 0.06 & $0.29 * * *$ & $0.99 * * *$ & $0.18 * * *$ & $0.56^{* * *}$ \\
\hline Wholesale \& retail & $0.04 * * *$ & 0.05 & $-0.04 *$ & -0.12 & $0.06 * *$ & 0.09 & -0.03 & -0.12 \\
\hline $\begin{array}{r}\text { Real estate \& social } \\
\text { services }\end{array}$ & $-0.05 * * *$ & $-0.29 *$ & -0.02 & $-0.32 * *$ & $0.24 * * *$ & $0.55 * * *$ & $0.07 * * *$ & 0.11 \\
\hline $\begin{array}{r}\text { Health \& welfare } \\
\text { services }\end{array}$ & -0.02 & -0.04 & -0.03 & -0.05 & $0.20 * * *$ & $2.06^{* * *}$ & $0.18^{* * *}$ & 0.42 \\
\hline Education & -0.02 & -0.12 & $0.06 *$ & 0.10 & $0.23 * * *$ & $1.33 * * *$ & $0.16^{* * *}$ & $0.60 *$ \\
\hline Scientific research & 0.02 & 0.04 & $0.21 * * *$ & $0.57 * *$ & $0.23 * * *$ & $1.29 * * *$ & $0.24 * * *$ & 0.83 \\
\hline Finance & 0.01 & 0.29 & $0.31 * * *$ & $0.97 * * *$ & $0.45 * * *$ & $2.00 * *$ & $0.20 * * *$ & 0.37 \\
\hline Government & $-0.05 * * *$ & -0.12 & 0.01 & 0.12 & $0.25 * * *$ & $0.91 * * *$ & $0.14 * * *$ & 0.47 \\
\hline
\end{tabular}

Notes: (1) *** denotes statistical significance at the $1 \%$ level; $* *$ at $5 \%$ and $*$ at $10 \%$ levels.

(2) Dependent variables: income $=\log$ of real income per capita; income gap = log of real income per capita; censored at $\$ 3$ per day; non-poor $=1$ if real income per capita above $\$ 3$ per day

(3) For occupation, ownership and industrial sector, controls for "other" and "not in above" included but not reported.

(4) Also included in models but not reported: head's age and age squared education, sex and CP membership; dependency ratio and log number of adults; provincial dummies and quadratics for age of household head. 


\section{Figure 1: Urban income per capita growth}

\section{rates by decile}

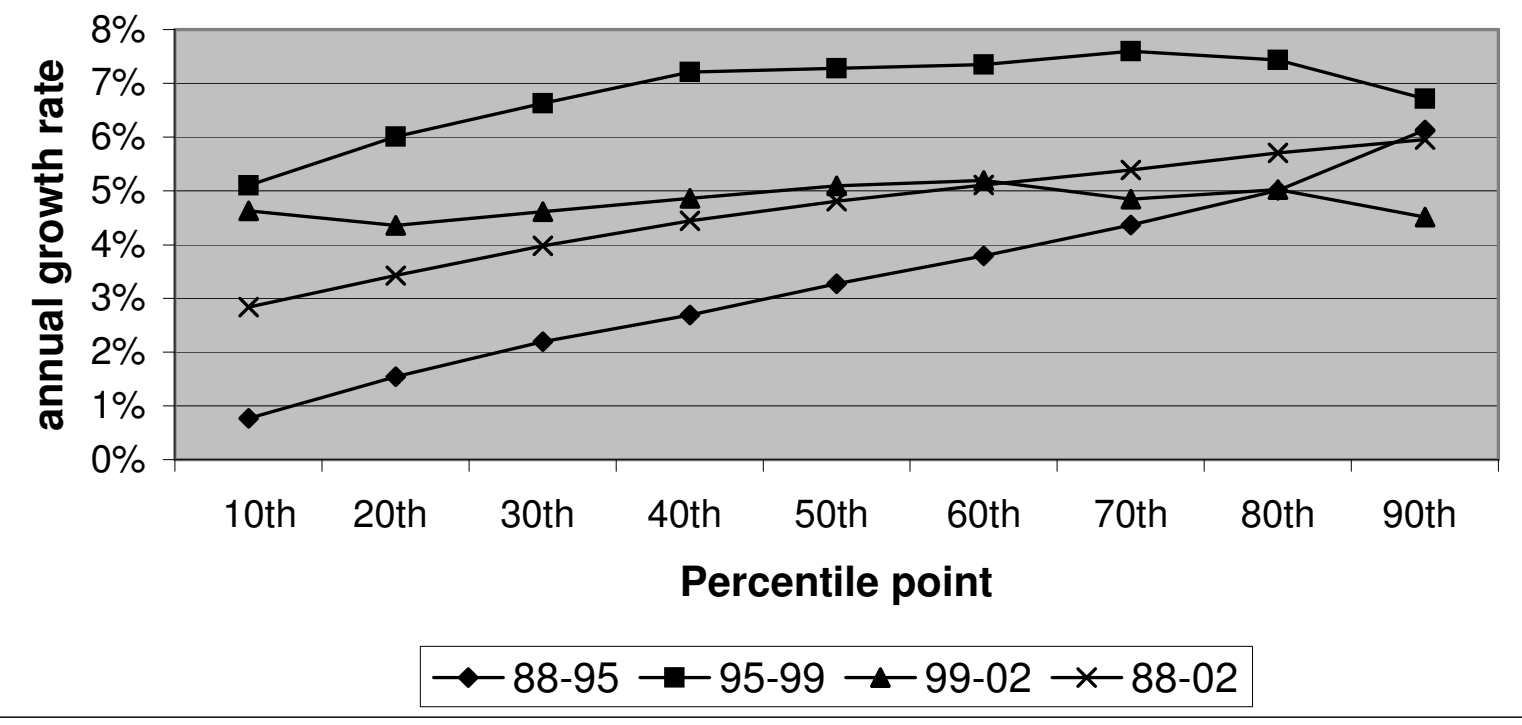




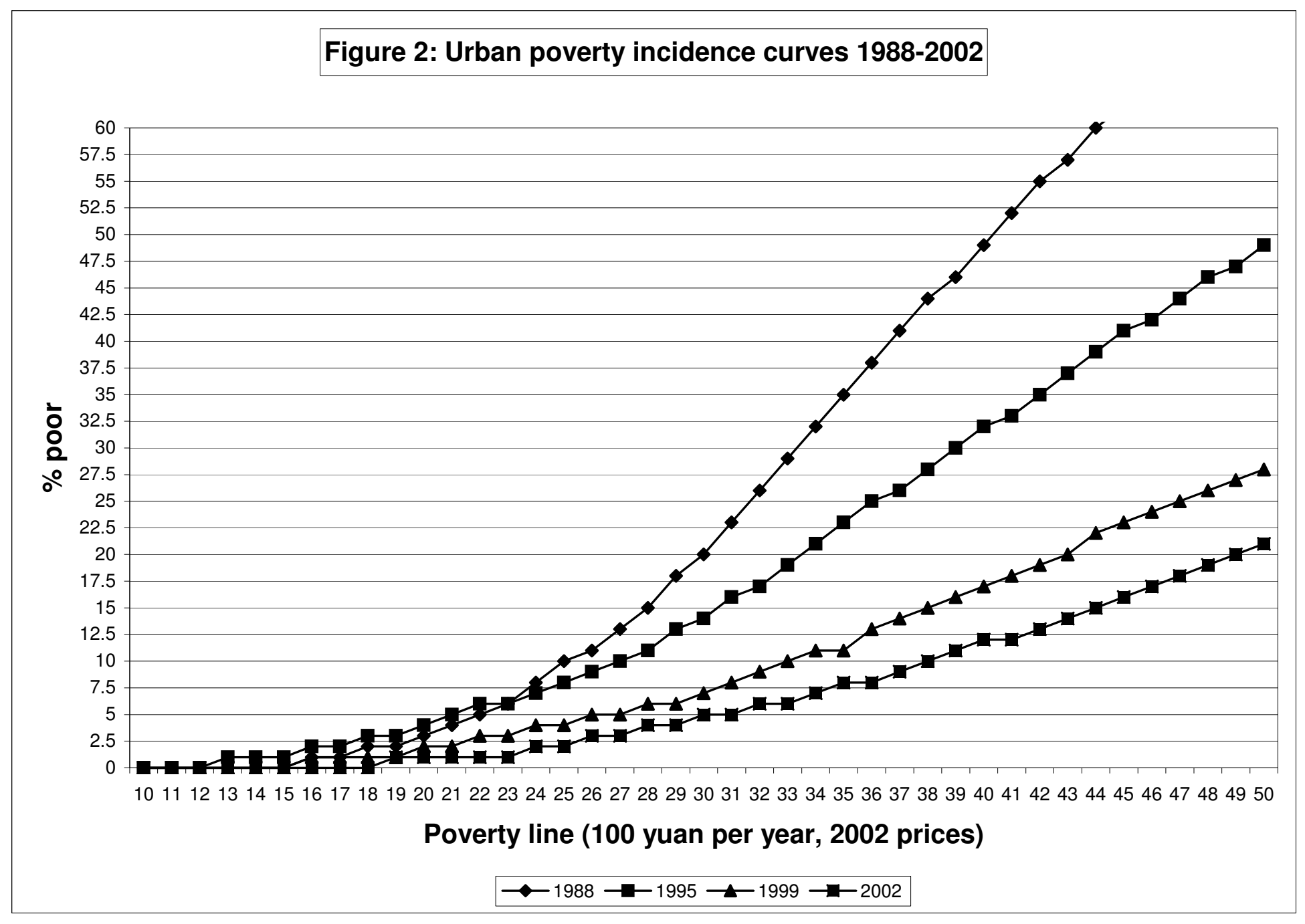




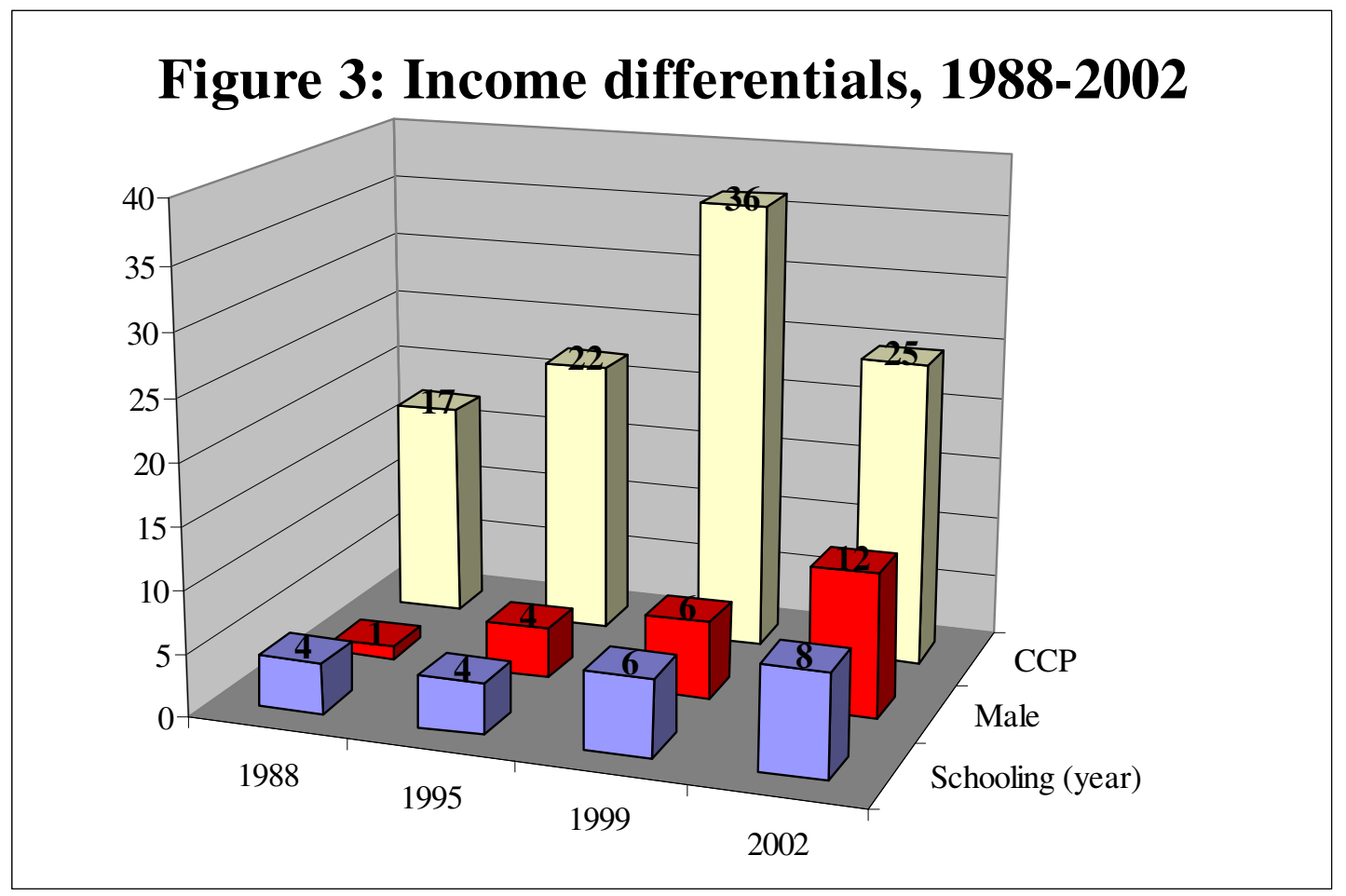

Figure 4: Income differentials by age of household head

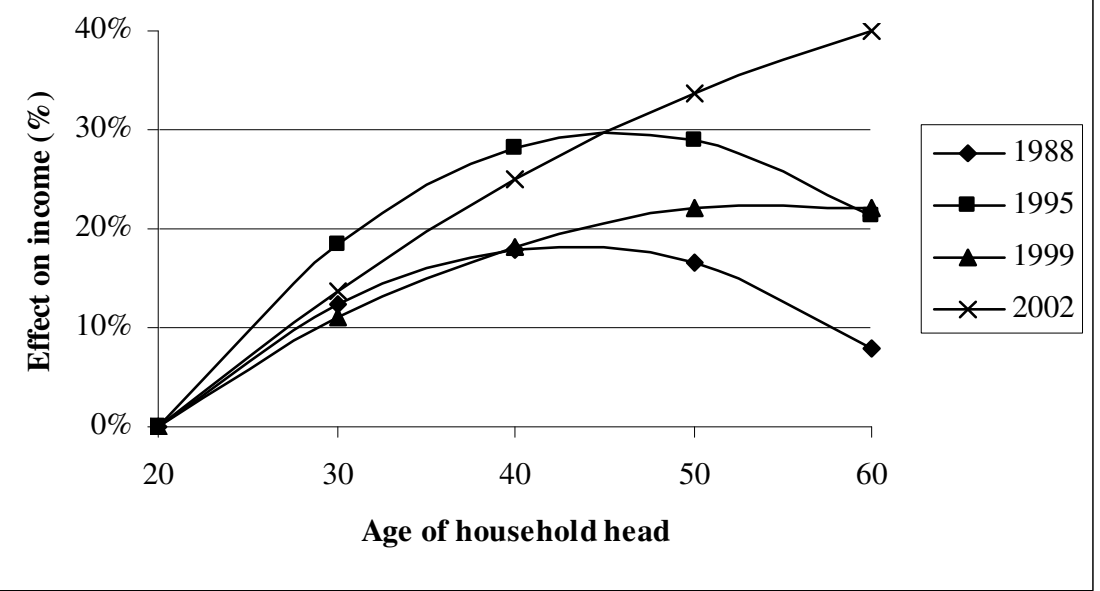


${ }^{1}$ For example, the 1995 survey covered 7,000 urban households from 68 cities in 11 provinces.

${ }^{2}$ The excluded "floating population" was estimated to constitute about $20 \%$ of all people actually in urban areas of China in 1995 and since then the proportion is likely to have increased.

${ }^{3}$ Income is used rather than consumption because that was the focus of the surveys that we analyse. This may be significant as some work using the National Bureau of Statistics (NBS) data on urban household incomes and expenditures finds that incomes rose more than expenditures during the period, reflecting an increase in savings rates (Meng et al., 2005).

${ }^{4}$ Payments by work units were often to retrenched State workers and as such came into prominence in 1998 during the period of retrenchment.

${ }^{5}$ This is calculating the differential by $\exp (\beta)-1$ where $\beta$ is the coefficient on CCP membership. 